\title{
EVENT RISK COVENANTS, DESIGN PARAMETERS AND AGENCY ISSUES: A COMPARATIVE STUDY OF HIGH YIELD VERSUS INVESTMENT GRADE BONDS
}

\author{
Manish TEWARI \\ Menlo College, Atherton, United States of America \\ E-mail:manish.tewari@menlo.edu
}

Received 06 October 2018; accepted 22 November 2018

\begin{abstract}
We analyse security design parameters of 1,115 high yield (HY) and investment grade (IG) event risk covenants (ERC) protected issues between 1986 and 2012 from the agency conflict perspective. We find positive and significant stock price reaction to the issuance of HY but not the IG issues. Although, majority of these issues carry a call provision, we find significant design differences in the call provision between HY and IG issues. We find that HY issues provide strong call protection to mitigate the risk of a call due to ratings upgrade, compromising firm's financial flexibility; resulting financial distress is mitigated by the ERC. IG issues provide weak call protection to fully exploit growth options however, role of ERC is not apparent. We also find evidence of increase in managerial entrenchment due to the presence of ERC in HY firms however, reduction in agency cost of debt supersedes cost of managerial entrenchment.
\end{abstract}

Keywords: corporate finance, financing, event risk covenants, callable debt, structured provisions, agency conflict.

JEL Classification: G320.

\section{Introduction}

The firms use debt provisions as the effective contracting mechanisms to counter the agency issues. The debt as a source of financing mitigates the agency conflict between stockholders and managers (agency cost of equity) by limiting the discretionary free cash flow (Jensen 1986, Stulz 1990) or introducing the fear of losing the firm to bondholders (Harris and Raviv 1990). The firms design debt provisions and engineer covenants to address market frictions and imperfections. Helwege et al. (2016) find that the firms with weaker debt covenant protection earn a higher risk adjusted equity returns and the effect is accentuated in the firms with more severe agency conflict between shareholders and bondholders. Zhang and Zhou (2018) find positive association between block ownership and number of bond covenants suggesting that bond covenants are included to mitigate agency issues between equity holders and bondholders. The literature is rife with reasons for the inclusion of one such covenant, event risk covenants (ERC hereafter) in the bond indenture. The ERC allow investors to sell the bonds back to the firms typically at the par value (and in some cases a higher coupon reset; Fields et al. (1994)) in case of a major firm restructuring and a subsequent ratings downgrade. The ERC are designed to protect investors from a fall in the bond values due to leverage inducing restructuring activities (Crabbe 1991) ${ }^{1}$ and are also commonly referred to as poison or super poison put.

Most of the studies related to the effect of ERC on market frictions have analysed the ERC protected bonds as a homogenous group. Bae et al. (1994) analyse the stock price reaction to the announcement of non-convertible ERC bonds and find positive price reaction due to the mitigation of agency cost of debt. Other studies (Roth and Mcdonald

Crabbe (1991) provides a detailed list of the types of restructuring events and the types of ratings downgrade by the relevant rating agency (S\&P and Moody's) that are likely to trigger ERC.

Copyright (c) 2018 The Authors. Published by VGTU Press.

This is an Open Access article distributed under the terms of the Creative Commons Attribution License (http://creativecommons.org/licenses/by/4.0/), which permits unrestricted use, distribution, and reproduction in any medium, provided the original author and source are credited.. 
1999, Cook and Easterwood 1994) in non-convertible bonds and Nanda and Yun (1996) in convertible bonds, find negative announcement effect due to the managerial entrenchment. These studies differ in their interpretation of the announcement dates.

We argue that since the HY and IG firms encounter disparate market frictions, the effectiveness of ERC must be analysed separately in the HY and the IG issues. We provide a comparative analysis of the stock price reaction to the inclusion of ERC in the HY and IG issues and its ability/inability to address agency conflicts. We analyse the announcement effect (CAR) at the issuance of ERC protected non-convertible fixed coupon bonds issued during 1986-2012. Majority of these bonds (87\% of the sample) also contain another important provision: call provision. The call provision allows the firms to call the issues back at a predetermined price and time; on the other hand, it increases the possibility of loss of income to investors due to a premature redemption (Winn and Hess 1959). Design of call provisions allows the firm to mitigate the agency conflict due to the investor's reinvestment risk (call due to declining interest rates (Kish and Livingston 1992)), ratings-upgrade risk (call due to credit ratings improvement in high-risk firms (Diamond 1991)), and growth-options risk (call due to realization of growth options in low-risk firms (Bodie and Taggart 1978)). The presence of strong call protection, call premium, or both signal high likelihood of a call while, weak call protection, call at par, or both signal weak likelihood of a call (Tewari et al. 2015).

(Tewari et al. 2015) contend that regardless of the reason(s) for the call, the likelihood of a call increases as the firm's refinancing risk decreases. Essentially, HY firms characterized by small size, high leverage, and presence of opacity; face lower refinancing risk from significant effect of ratings upgrade thereby, present high ratings-upgrade risk regardless of the level of interest rates. High quality IG firms characterized by larger size, low leverage, and growth options (Guedes and Opler 1996) generally, face lower refinancing risk and consequently, present high growth-options risk in all environments and reinvestment risk in the high rate environment. Low rated IG firms possess fewer growth options (lower quality projects) and present low growth-options risk. Since majority of the IG issues in the sample provide weak call protection and fall in the lower half of the IG rating spectrum, they present low ratingsupgrade risk and low growth-options risk. We find that the IG firms in the sample issue majority of the issues in the low interest rate period (2007 and after) virtually eliminating their exposure to declining interest rates and consequently, investors' reinvestment-risk. In summary, investors in the ERC protected callable $\mathrm{HY}$ debt face high ratings-upgrade risk on one side and financial distress on the other if the ratings improvement fails to materialize; the low rated IG issues in low interest rate environment, face low ratings-upgrade, growth-options, or reinvestment risk but high ratings downgrade risk if the growth options do not materialize.

In addition to the call provision, the firms also use debt maturity to address agency conflicts. Short maturity bonds are likely to reduce underinvestment and asset substitution problems (Nash et al. 2003) especially, in risky debt (Thatcher 1985). Xu (2017) finds that the HY issuing firms frequently retire debt early and refinance to manage bond maturity. Almost all the HY issues and majority of the IG issues in the sample contain short maturity ( $\leq 20$ years) bonds.

Begley (1994) provides empirical evidence that the firms' choice of covenants is a trade-off between perceived benefits and costs. The presence of ERC and call provision in the issues might have countervailing effect. We delve deep into the details of the call provision (strength of call protection and call premium) to understand relative effect(s) of call and ERC on the firm, as estimated by the stock price reaction.

The stylized facts and the empirical analysis with CAR as the dependent variable, provide evidence that the strong call protection accompanied by the call premium is instrumental in significantly reducing the agency costs associated with the ratings-upgrade risk in HY issues; the resulting financial distress from restrictive covenant is mitigated by ERC. The IG issues provide weak call protection callable at par, affording the issuing firms financial flexibility in fully exploiting fewer growth options on one hand; signalling lower possibility of a call on the other. The insignificant stock price reaction does not support the hypothesis that ERC mitigate the financial distress due to failure to realize growth options. Although, we find that the ERC increase managerial entrenchment in HY firms as suggested by Billet et al. (2007), the net effect is positive since the reduction in the ratings-upgrade risk and subsequent financial distress is greater than the increase in managerial entrenchment, affirming Bae et al. (1994). The rest of the paper is divided into five sections; Literature review and hypotheses development, description of sample and descriptive statistics, event study, regression results, and conclusions.

\section{Literature review and hypotheses development}

\subsection{ERC, Agency issues, and market frictions}

ERC can burden potential acquirer with additional costs due to contractual obligations (Cook and Easterwood 1994); which is likely to deter acquisition, leading to managerial entrenchment (Kahan and Klaussner 1993). Roth and McDonald (1999) find evidence that ERC in bonds increase managerial entrenchment. Shleifer and Vishny (1989) find negative wealth effect of managerial entrenchment due to increase in the agency cost between the 
managers and the stockholders. Ghouma (2017) finds that lower level of managerial entrenchment is associated with lower corporate bond costs and higher bond credit ratings. Billet et al. (2007) finds that the firms with risky debt outstanding are less likely to be a takeover target. Billet et al. (2015) find that the cost of debt relative to the cost of equity declines for the firms with high agency costs of equity. We argue that the managerial entrenchment in $\mathrm{HY}$ issuing firms should be more pronounced due to ERC. In the event of a firm undergoing LBO, ERC can prevent wealth transfer from the bondholders to stockholders (Warga and Welch 1993) thereby, reducing agency cost of debt (Jensen and Meckling 1976). Bhanot et al. (2010) find higher negative correlation between stock returns and bond spread changes in firms with ERC bonds facing takeover threat. Asquith and Wizman (1990) and Cook et al. (1992) find evidence that unprotected bonds suffer significant wealth transfer. In addition, Perumpral et al. (1999) argue that ERC necessitate negotiations between potential acquirer and target managers, serving the interest of both bondholders and shareholders. Hege and Hennessey (2010) argue that the ERC benefit stockholders in two ways; first, through reduction in merger surplus to the potential acquirers; second, enjoy same merger surplus through lower debt value. These potential benefits of the ERC manifest into reduced financing cost for the firm in terms of reduced yield spreads (Cremers et al. 2007, Crabbe 1991). We argue that reduced yields due to ERC should have more pronounced effect in HY issues.

In addition, the ERC have potential to reduce the cost of bankruptcy to the bondholders in case of firms with high risk of default (Leland 1994). Smith et al. (1989) contend that as the firm's value declines due to increasing financial distress, the underinvestment and asset substitution problems worsen leading to increase in the agency cost between bondholders and the stockholders. The firm in financial distress are more likely to include ERC in bond issues in order to counter this agency issues (Nash et al. 2003).

\subsection{Call provision}

The call provision has potential to mitigate interest rate risk for the firms (Kish and Livingston 1992), informational asymmetry and asset substitution (Barnea et al. 1980), and underinvestment for the firms with growth options (Bodie and Taggart 1978). The call provision can be used to signal bright future prospects for the firm (Robbins and Schatzberg 1986, Ederington and Stock 2002). Korkeamaki and Moore (2004) argue that the firms engineer the strength of call protection to allow sufficient flexibility in the timing of future investments. Tewari et al. (2015) argue that the covenants that weaken call protection are likely to increase refunding risk for the investors from an early call due to the falling interest rates or credit ratings improvement. The firms engineer call provision parameters to counter these risks.

\subsection{Financial flexibility, financial distress and growth options}

According to Nash et al. (2003) financial flexibility is very important for the survival of the firms facing financial distress. McDaniel (1986) contends that less restrictions on potential financing choices provide greater flexibility in developing and implementing plans for the survival of firms in financial distress. Anderson (1999) finds that firms closer to financial distress are more likely to avoid restrictive covenants that reduce financial flexibility. Thatcher (1985) argues that the provisions that allow early redemption (weaken call protection) in firms with financial distress, increase financial flexibility and consequently mitigate agency costs. Begley (1994) claims that the cost of restrictive covenants largely depends on the restricted activities' contribution to shareholder wealth maximization.

Nash et al. (2003) state that the firms with high growth options are likely to value the financial flexibility more than the firms with low growth options. The firms with high growth options are likely to adopt less restrictive covenants to preserve financial flexibility to invest in high-quality projects (Kahan and Yermack 1998, Begley 1994, Anderson 1999, Gilson and Warner 1998). We argue that the firms with fewer growth options stand to benefit less from increased flexibility due to low quality projects.

Hypothesis: The above discussion and previous research on ERC and the call provision suggests that both provisions work in isolation from each other. Our thesis is that the ERC and the call provision in the bonds are designed to work in conjunction to reduce the agency problems associated with the debt issues.

\section{Sample}

The initial search on the Bloomberg Terminal for the US non-convertible fixed coupon ERC issues yields 2,086 $(1,116 \mathrm{HY}$ and $970 \mathrm{IG})$ issues between 1986 and 2012. There are 1,815 callable issues ( $87 \%$ of the total). The raw sample is further screened as follows: a) the issuing firm must be a publicly traded firm in the US and searchable on the CRSP and COMPUSTAT databases; and $b$ ) all but one of the multiple issues by the same firm within the 6-day event period are eliminated. The final sample consists of 1,115 (548 HY and 567 IG) issues. The final sample preserves all the characteristics and distributions of the raw sample ${ }^{2}$, as highlighted in this section, suggesting sample selection bias is not an issue. The issue specific information is obtained from Bloomberg database; the firm specific information is obtained from the COMPUSTAT database, and the stock prices are obtained from the CRSP database. We follow S\&P's alpha numeric rating to characterize issues as IG

\footnotetext{
2 Figure 1, 3, 5 depict rating, maturity, and annual distributions of the raw sample of 2,086 issues.
} 
Table 1. Industry classification

\begin{tabular}{|l|c|c|c|}
\hline \multicolumn{1}{|c|}{$\begin{array}{c}\text { Industry } \\
\text { Classification }\end{array}$} & All Issues & $\begin{array}{c}\text { High Yield } \\
\text { (HY) }\end{array}$ & $\begin{array}{c}\text { Investment } \\
\text { Grade (IG) }\end{array}$ \\
\hline Agriculture & 6 & 3 & 3 \\
\hline Construction & 47 & 43 & 4 \\
\hline $\begin{array}{l}\text { Finance, } \\
\text { Insurance \& Real } \\
\text { Estate }\end{array}$ & 101 & 57 & 44 \\
\hline Manufacturing & 453 & 152 & 301 \\
\hline $\begin{array}{l}\text { Mineral } \\
\text { Industries }\end{array}$ & 129 & 100 & 29 \\
\hline $\begin{array}{l}\text { Public } \\
\text { Administration }\end{array}$ & 0 & 0 & 0 \\
\hline Retail & 118 & 70 & 44 \\
\hline Service & 155 & 77 & 78 \\
\hline $\begin{array}{l}\text { Transportation, } \\
\text { Communications } \\
\text { \& Utilities }\end{array}$ & 22 & 6 & 16 \\
\hline Wholesale & 115 & 548 & 567 \\
\hline Total & & 40 & 48 \\
\hline
\end{tabular}

(BBB- or above) and HY (BB+ and below $)^{3}$. For the issues not provided letter rating by S\&P, we use Moody's rating. For the issues not rated by both, we use Bloomberg's HY/IG flag. The industry classification of the sample is presented in table 1. In this table we provide the industry classification of the full sample, HY, and IG event risk covenants protected bonds issued between 1986 and 2012.

\subsection{Numerical measure of rating and split rating}

In order to control the analysis for the rating of the sample issues, we convert S\&P and Moody's ratings to numerical rating (Table 2). In this table we provide the scale to convert S\&P rating and Moody's ratings into numerical measures. The issues not rated by either S\&P or Moody's but rated IG or HY by Bloomberg are assigned 11.5 and 3.0 rating values respectively. The Rating variable takes on the value of 16 for the issues rated AAA for S\&P and its equivalent Aaa for Moody's and one for the issues rated B- for S\&P and its equivalent B3 for Moody's. The issues rated below B- for S\&P and B3 for Moody's are assigned the numerical value of zero. According to this numerical conversion, the average value of Rating for the IG issues (AAA to BBB-for S\&P and Aaa to Baa3 for Moody's) is 11.5 and the average value of Rating for the $\mathrm{HY}$ issues (BB+ and below for S\&P and $\mathrm{Ba} 1$ and below for Moody's) is 3.0. We use the average numerical measures (11.5 for IG and 3.0 for HY) for all the issues not rated by both S\&P and Moody's but provided HY/IG flag by Bloomberg. The average Rating of the IG

3 We perform complete analysis by using Moody's alpha numeric rating to characterize IG and $\mathrm{HY}$ issues in order to account for split between S\&P and Moody's. The results are essentially the same.

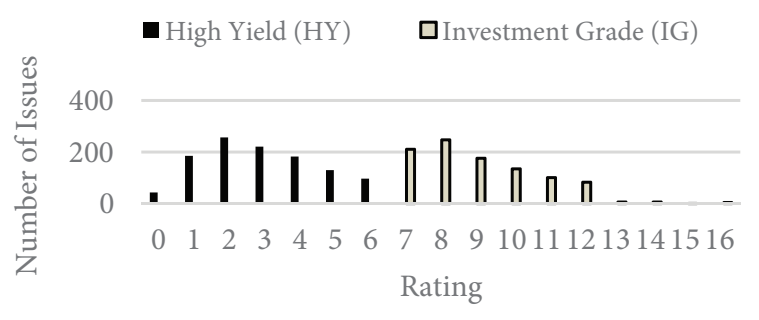

Figure 1. Rating distribution of High Yield (HY) and Investment Grade (IG) Event Risk Covenants Protected (ERC) bonds for the raw sample

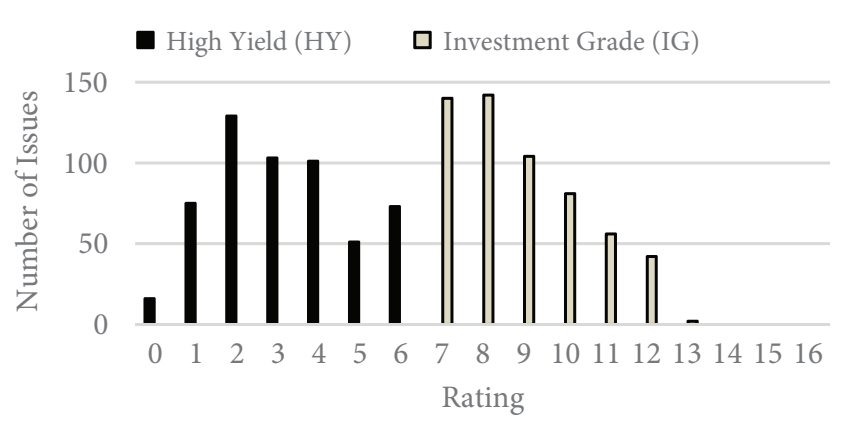

Figure 2. Rating distribution of High Yield (HY) and Investment Grade (IG) Event Risk Covenants Protected (ERC) bonds for the final sample

issues in the sample is 8.8 while the average Rating of the HY issues is 3.2. The Rating distribution of the final sample (Figure 2) ${ }^{4}$ shows that the IG issues are concentrated in the lower spectrum of the IG rating scale.

For the sample of 1,115 issues, the S\&P and Moody's are split rated by one notch or more in 584 issues (261 IG and $323 \mathrm{HY}$ ). Split rating between the rating agencies indicates presence of opacity and the presence of higher level of information asymmetry. We introduce Split variable (binary) which takes on the value of 1 in the case of split rated issues and zero otherwise. Rating for the split rated issues is calculated using the S\&P ratings ${ }^{5}$ as in Avramov et al. (2007).

\subsection{Other protective covenants}

The firms are likely to include other protective covenants (in addition to ERC and Call provision) to counter the agency cost of debt (Billet et al. 2007). The presence of these covenants is likely to elicit market reaction at the issuance. We identify the presence of other covenants in the sample issues from Bloomberg. A list of these protective covenants includes; equity call, net worth call, poison pill call, sinking fund, collateralized by the asset type, additional backup

\footnotetext{
4 This rating distribution of HY and IG issues is consistent in the raw sample of 2,086 issues where average rating of HY issues $=2.99$ and the average rating of IG issues $=8.99$.

5 The analysis is also performed by using numerical value of Moody's ratings and by also taking the average of Moody's and S\&P ratings for the split rated issues. Results are essentially the same.
} 
guarantee, subordination, limitations on additional debt, and limitation on dividend. In order to control for other covenants, we introduce the Covenant variable (binary) that takes on the value of 1 if any of these additional covenants are present and zero otherwise. There is a total of 232 issues (51 IG and $181 \mathrm{HY}$ ) with the presence of at least one of the above-mentioned other covenants.

\subsection{Descriptive statistics}

In Table 3, Panel A we provide the descriptive and comparative statistics of the HY and IG issues. The firms with IG issues are significantly larger (avg. total assets $=\$ 23.3 \mathrm{~B}$; avg. market value ${ }^{6}=\$ 14.8 \mathrm{~B}$ ) than the ones with $\mathrm{HY}$ issues (avg. total assets $=\$ 6.0 \mathrm{~B}$; avg. market value $=\$ 2.6 \mathrm{~B})$. The principal amount raised through the IG issues is significantly larger (avg. principal amount $=\$ 465.5 \mathrm{M}$ ) than the HY issues (avg. principal amount $=\$ 299.1 \mathrm{M}$ ). The leverage denoted by Debt Ratio (total debt/total assets) of the IG issuing firms (avg. of 30.3\%) is significantly lower than that of the HY issuing firms (avg. of 48.0\%). These facts identify firms issuing HY bonds as the small firms with high level of debt. 534 of the IG issues and 488 of the HY issues are issued by the industrial firms.

The average coupon rate for the IG issues is $5.8 \%$, which is significantly lower than the average coupon rate of the HY issues of $8.9 \%$, as expected. The average Tobin's $Q^{7}$ (as a measure of growth options) immediately before the issuance for the IG issuing firms is 1.25 as compared to the HY issuing firms of 1.04. The IG issuing firms possess more growth options.

\subsection{Free cash flow as a measure of managerial entrenchment}

We use free cash flow $(F C F)$ and the as the measures of the managerial entrenchment. Jensen (1986) contends that the firms with higher FCF are likely to face a higher level of agency cost of equity due to the managerial indiscretion. Billet et al. (2007) contends that the firms with risky debt outstanding are less likely to be takeover targets. We contend that ERC in HY issues can further exacerbated managerial entrenchment. The FCF is calculated using the approach by Lehn and Poulson (1989) and Bae et al. (1994). The average of FCF as a percentage of total assets for both the IG and HY issuing firms is about $7 \%$.

\subsection{Maturity}

The average Maturity of the IG issues (12.5 years) and the HY issues (9.3 years) is deemed short maturity on the scale

\footnotetext{
6 Market Value immediately prior to the issue date $=$ closing stock price $\mathrm{X}$ number of shares outstanding.

7 Tobin's Q $=($ Market value of Equity + Book Value of Assets - Book Value of Equity)/Book Value of Assets.
}

Table 2. Numerical conversion of S\&P and Moody's ratings

\begin{tabular}{|c|c|c|c|}
\hline $\begin{array}{c}\text { S\&P } \\
\text { Rating }\end{array}$ & $\begin{array}{c}\text { Moody's } \\
\text { Rating }\end{array}$ & $\begin{array}{c}\text { Numerical } \\
\text { Rating }\end{array}$ & Classification \\
\hline AAA & Aaa & 16 & \multirow{10}{*}{$\begin{array}{l}\text { Mean } \\
\text { Investment } \\
\text { Grade (IG) } \\
\text { Numerical } \\
\text { Value = } 11.5\end{array}$} \\
\hline $\mathrm{AA}+$ & Aa1 & 15 & \\
\hline $\mathrm{AA}$ & $\mathrm{Aa} 2$ & 14 & \\
\hline AA- & Aa3 & 13 & \\
\hline$A+$ & A1 & 12 & \\
\hline A & $\mathrm{A} 2$ & 11 & \\
\hline A- & A3 & 10 & \\
\hline $\mathrm{BBB}+$ & Baal & 9 & \\
\hline BBB & $\mathrm{Baa} 2$ & 8 & \\
\hline BBB- & Baa3 & 7 & \\
\hline $\mathrm{BB}+$ & Bal & 6 & \multirow{6}{*}{$\begin{array}{l}\text { Mean } \\
\text { Investment } \\
\text { Grade (HY) } \\
\text { Numerical } \\
\text { Value = } 3.0\end{array}$} \\
\hline BB & $\mathrm{Ba} 2$ & 5 & \\
\hline BB- & $\mathrm{Ba} 3$ & 4 & \\
\hline $\mathrm{B}+$ & $\mathrm{B} 1$ & 3 & \\
\hline B & $\mathrm{B} 2$ & 2 & \\
\hline B- & B3 & 1 & \\
\hline Below & Below & 0 & \\
\hline
\end{tabular}

of short maturity ( $\leq 20$ years) and long maturity ( $>20$ years). Firms issue majority of ERC protected bonds with short maturity. The maturity distribution of both HY and IG issues is similar (Figure 3 - Raw Sample and Figure 4 Final Sample $)^{8}$ with majority of both issues concentrated between 10 and 15 years. This pattern is more consistent in $\mathrm{HY}$ issues with $97 \%$ of the issues in 10-15 years range. We note that the maturity distribution of $75 \%$ of IG issues fall in 10-15 years range and a total of 105 IG issues (19\% of the total) fall in the 25-35 years range (long maturity).

\subsection{Refundable and make-whole call: provisions that weaken the call protection}

The firms issuing callable debt can significantly weaken the call protection by including the Refundable or MakeWhole provisions. Both of these provisions allow the firms to call the debt during the call protection period ${ }^{9}$. We find extensive use of Refundable/Make-Whole provision in the IG issues ( $81 \%$ of the total IG issues) ${ }^{10}$ to weaken the Call Protection (average $=4.3$ years). This observation is consistent with the finding that firms with growth options

\footnotetext{
8 The maturity distribution of HY and IG issues in raw sample $(2,086)$ exhibits the same characteristics where $98 \%$ of the HY issues and $80 \%$ of IG issues have short maturity.

9 The firms can use Refundable provision to call if the funds obtained to retire the debt are not raised through new lower cost debt. The MakeWhole allows early call at the price calculated by discounting all the future cash flows at the discount rate of treasury plus a spread.

${ }^{10} 77 \%$ of the IG issues and $21 \%$ of the HY issues in the raw sample contain refundable/make-whole provision.
} 


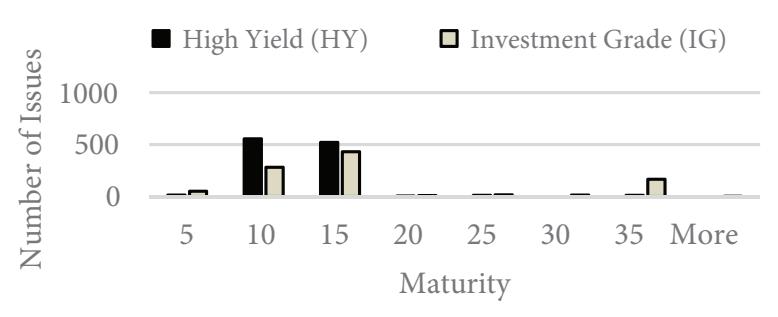

Figure 3. Maturity distribution of High Yield (HY) and Investment Grade (IG) Event Risk Covenants Protected (ERC) bonds for the raw sample

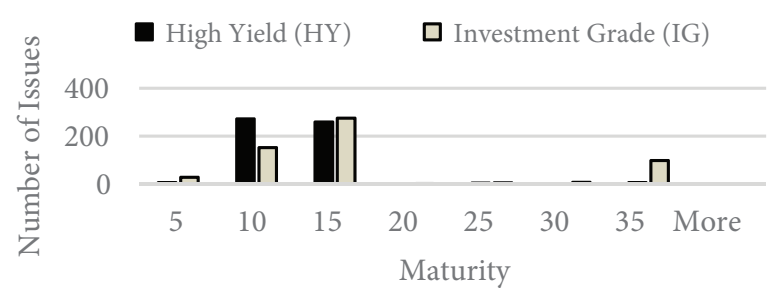

Figure 4. Maturity distribution of High Yield (HY) and Investment Grade (IG) Event Risk Covenants Protected (ERC) bonds for the final sample

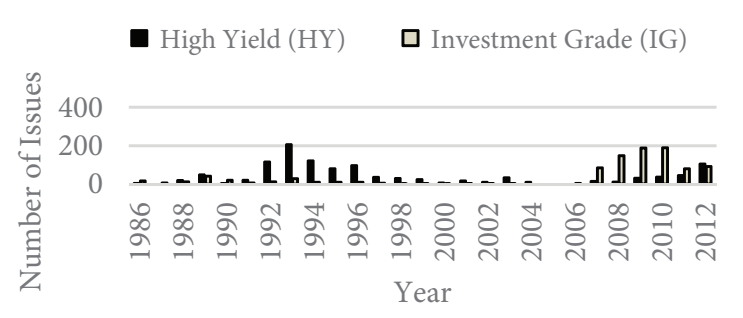

Figure 5. Distribution of High Yield (HY) and Investment Grade (IG) Event Risk Covenants Protected (ERC) bonds by year for the raw sample

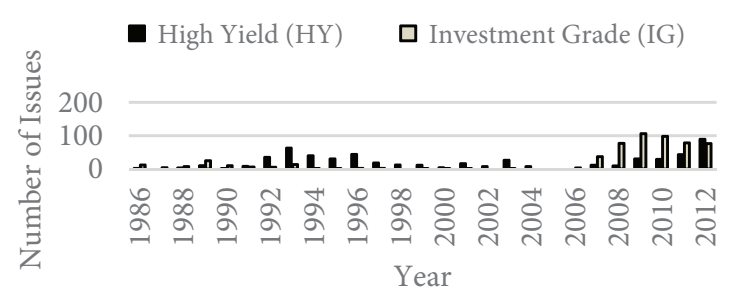

Figure 6. Distribution of High Yield (HY) and Investment Grade (IG) Event Risk Covenants Protected (ERC) bonds by year for the final sample

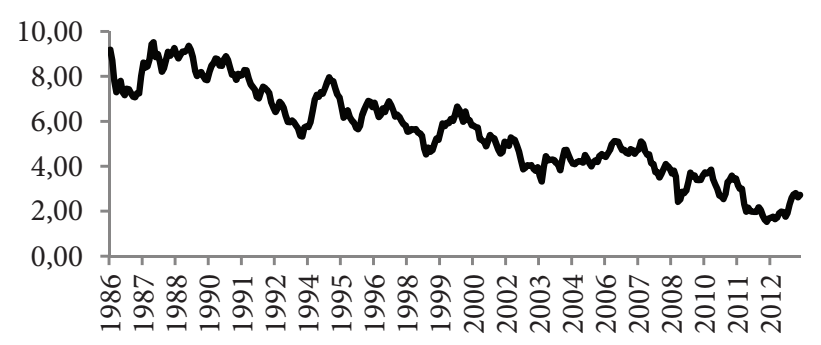

Figure 7. Ten-year constant maturity monthly treasury rates with monthly frequency for the period 1986-2012 are likely to adopt less restrictive covenants ((Kahan and Yermack 1998, Begley 1994, Anderson 1999, Gilson and Warner 1998).

In the HY issues, we find sparse use (34\% of total HY issues) of Refundable/Make-Whole provision indicating the effort by the firms to provide strong Call Protection (average $=4.6$ years). This is contrary to findings that the firms in financial distress avoid protective covenants to preserve financial flexibility (Thatcher 1985, Anderson 1999). We introduce a binary variable Refund/MW (= 1 when refundable/make-whole present, 0 otherwise) to assess the importance of the strength of call protection in HY issues.

\subsection{Call premium}

Firms face a choice of compensating investors for a higher risk of early call by either compensating them with a call premium or paying a higher yield (coupon). Firms set the call prices of non-convertible fixed coupon issues at either the par value or at a premium equal to the par value plus the annual coupon amount. Tewari et al. (2015) find that the firms compensate investors with a call premium in the case of an early call to mitigate investor's refunding risk. They contend that call premium is a more effective contracting mechanism since it is the cost firm pays only when the call occurs.

\subsection{Annual distribution of HY and IG bonds}

The annual distribution of the number of issues of $\mathrm{HY}$ and IG issues (Figure 5 - Raw Sample and Figure 6 - Final Sample) is clearly distinct. The majority of the HY issues are concentrated around the period 1992-1996 and 20092012. While, the majority of the IG issues are concentrated around the period 2007-2012 (period around the financial crisis). The level of interest rates is one of the determinants of the choice of maturity (short $\leq 20$ years or long $>20$ years) of bonds (Tewari et al. 2015) and the likelihood of the bonds being called (Kish and Livingston 1992). In order to control for the level of interest rates at the bond issuance, we follow the methodology of low and high interest rate regimes as in (Tewari et al. 2015). We set 1986-1997 as the period for high interest rates and 1998-2012 as the period for low interest rates based on the median value $5.46 \%$ in 1998) of the ten-year rate posted with monthly frequency by the Federal Reserve for the period 1986-2012 (Figure 7). The sample indicates that the HY issues are issued during both high and low interest rate regimes while the IG issues are issued during low interest rate regime or the period around the financial crisis.

\section{Event study}

We use the traditional event study methodology (Scholes and Williams 1977) with pre-event estimation window of 
$[-255,-46]$ trading days prior to the event date $(0)$. We use issue date as the event date and the 6-day event window as in Harvey et al. (2004) to calculate CAR. We use the event window of 6 days $(-1,+4)$ where -1 corresponds to the day before the issue date, 0 the issue date, and +4 the 4 days after the issue date. Harvey et al. (2004) find, on the basis of public news sources, that typical announcement of debt issues occurs on or after the issue date. Even if the announcement precedes the issued date, there is an uncertainty about the completion of the financing. Due to this reason Mikkelson and Partch (1986) contend that the measurement of the announcement effect of the debt issue is unlikely to fully capture the actual benefits of the debt contract. For the issues where announcement precedes the issue date (Miller 1999), chances of finding significant effect on the issue date are considerably lowered. We recognize that the event study is likely to capture the value effect of the exogenous changes in discretionary cash flow in all the debt issues (Jensen 1986, Stulz 1990), we assume it to be constant across all issues in the sample.

\subsection{Event study results}

The event study results for the $(-1,+4)$ event window for the full sample, HY issues, and the IG issues are presented in Table 3, panel B. We find positive average CAR $(0.23 \%)^{11}$ for the full sample significant at 5\%. Individual event study for the HY and IG issues reveal this can be attributed to the $\mathrm{HY}$ issues. For $\mathrm{HY}$ issues, we find positive average CAR $(0.29 \%)$ significant at $5 \%$ level while statistically insignificant CAR for the IG issues.

\section{Regression results}

We perform cross-sectional regression analysis with CAR as the dependent variable to explain the likely reasons for the positive stock price reaction for HY issues and not for IG issues. Table 4 contains results for the full sample $(1,115)$ and Table 5 contains results for HY issues (548) and for the IG issues (567). We perform separate regressions on HY and IG issues to test the robustness of the results and interpret the observations in the full sample regression.

Firm Specific Control Variables with expected signs in parenthesis (HY, IG; reasons): We use Total Assets to control for the firm size $(+,+$; larger firm enjoy lower agency cost and refinancing risk), Debt Ratio for the financial leverage $(+,+$; firms with higher leverage benefit from ERC), SIC for the industry ( $=1$ for industrial firms, $=0$ for finance, insurance, real estate, telecommunications, transportation, and

\footnotetext{
${ }^{11}$ We check Wall Street Journal and the business magazines on LexusNexus for any confounding events (atypical earnings, bankruptcies, dividend changes, capital structure changes, restructuring, privatization, asset write offs, and board changes) over the period two weeks prior and two after the issue date and find 52 such issues. The results remain unchanged after removing these issues.
}

Table 3. Descriptive Statistics and Average Cumulative Abnormal Return (CAR)

\begin{tabular}{|c|c|c|c|c|c|}
\hline \multicolumn{6}{|l|}{ Panel A: } \\
\hline \multirow{2}{*}{$\begin{array}{l}\text { Charac- } \\
\text { teristics }\end{array}$} & \multicolumn{2}{|c|}{ High Yield (HY) } & \multicolumn{2}{|c|}{ Invest. Grade (IG) } & \multirow[t]{2}{*}{ T- Stat } \\
\hline & Mean & \# Issues & Mean & \# Issues & \\
\hline \multicolumn{6}{|c|}{ Issue Specific } \\
\hline $\begin{array}{l}\text { Principal } \\
\text { (\$Mil) }\end{array}$ & 299.11 & & 465.45 & & $-8.814^{\star \star \star}$ \\
\hline Maturity & 9.28 & & 12.55 & & $-8.257^{* * *}$ \\
\hline $\begin{array}{l}\text { Coupon } \\
(\%)\end{array}$ & 8.92 & & 5.83 & & $24.122^{\star \star \star}$ \\
\hline Rating & 3.17 & & 8.82 & & $-58.649^{\star * *}$ \\
\hline $\begin{array}{l}\text { Call Pro- } \\
\text { tection }\end{array}$ & 4.60 & & 4.31 & & 0.817 \\
\hline Callable & & 487 & & 486 & \\
\hline $\begin{array}{l}\text { Refund/ } \\
\text { MW }\end{array}$ & & 184 & & 458 & \\
\hline Premium & & 413 & & 123 & \\
\hline Covenants & & 181 & & 51 & \\
\hline Split & & 323 & & 261 & \\
\hline \multicolumn{6}{|l|}{$\begin{array}{l}\text { Firm } \\
\text { Specific }\end{array}$} \\
\hline $\begin{array}{l}\text { Total } \\
\text { Assets } \\
(\$ B i l) \\
\end{array}$ & 6.00 & & 23.31 & & $-3.793^{\star * *}$ \\
\hline $\begin{array}{l}\text { Market } \\
\text { Value } \\
(\$ B i l)\end{array}$ & 2.62 & & 14.81 & & $-15.393^{\star * *}$ \\
\hline $\begin{array}{l}\text { Debt Ratio } \\
(\%)\end{array}$ & 48.03 & & 30.33 & & $17.134^{\star * *}$ \\
\hline $\begin{array}{l}\text { FCF } \\
\text { (\$Mill) }\end{array}$ & 404.97 & & 1642.05 & & $-12.783^{\star * *}$ \\
\hline Tobin's Q & 1.04 & & 1.25 & & $-6.216^{\star * *}$ \\
\hline \multicolumn{6}{|l|}{ Panel B: } \\
\hline Type & $\begin{array}{l}\text { Total } \\
\text { Issues }\end{array}$ & $\begin{array}{l}\text { Avg. } \\
\text { CAR }\end{array}$ & Z-Stat & $\begin{array}{l}\text { Positive: } \\
\text { Negative }\end{array}$ & $\begin{array}{c}\text { Generalized } \\
\text { Sign Z }\end{array}$ \\
\hline $\begin{array}{l}\text { Full } \\
\text { Sample }\end{array}$ & 1,115 & $0.23 \%$ & $1.943^{\star *}$ & $587: 528$ & $1.962^{\star *}$ \\
\hline $\begin{array}{l}\text { High Yield } \\
(\mathrm{HY})\end{array}$ & 548 & $0.29 \%$ & $2.135^{\star *}$ & 297:251 & $2.562^{\star * *}$ \\
\hline $\begin{array}{l}\text { Invest. } \\
\text { Grade (IG) }\end{array}$ & 567 & $0.15 \%$ & 1.142 & 290:277 & 0.928 \\
\hline
\end{tabular}

$* * *, * *$, and ${ }^{*}$ indicate significance at the $1 \%, 5 \%$, and $10 \%$ level for one-tailed test.

utilities) (-, -; higher refinancing risk for industrial firms), and Tobin's $Q$ for the growth options (+, +; high growth firms face lower refinancing risk).

Issue Specific Control Variables with expected signs in parenthesis for (HY, IG; reasons) issues: We use Principal to control for the issue size $(-,++$; larger principal increases refinancing risk in the HY but allows full exploitation of growth options in IG issues), Coupon for the bond yield (+, 
+; both benefit from lower yields due to ERC), Rating as a numerical measure $(+,+$; lower refinancing risk), Covenant for all other covenants apart from the call provision and ERC (-, -; more restriction hence lower flexibility), and Call Protection (years) (+, -; lower ratings-upgrade risk in $\mathrm{HY}$ and more restriction and lower flexibility in IG issues).

Test Variables with expected signs in parenthesis: $H Y(=1$ if issue is HY, $=0$ if IG) $(+$, ERC mitigates higher level of financial distress), Maturity to test if shorter maturity reduces agency cost of debt (-, -; short maturity characterized by lower agency cost of debt), Split to test the level of opacity $(-,-$; higher opacity leads to higher agency cost of debt), Refund/MW to test the effect of weaker call protection -, +; increases ratings-upgrade risk in $\mathrm{HY}$ but can provide more financial flexibility in IG issues), and FCF as a measure of managerial entrenchment (-, -; higher entrenchment due to ERC).

We find the Total Asset coefficient to be positive and significant at $1 \%$ in all the regressions as expected in Table 4 . Table 5 confirms that the Total Asset coefficient for both HY and IG issues are positive and significant. This observation affirms that the larger firms face lower refinancing risk. The coefficients for Debt Ratio, SIC, Principal, Covenants, and Call Protection are insignificant for all the regressions. The Tobin's $Q$ coefficient is positive and significant for all the regressions at $10 \%$ level (regression 5 at $5 \%$ ) as expected. The coefficient for Coupon is positive and significant in first three regressions at $1 \%, 5 \%$, and $5 \%$ and then becomes significant at $10 \%$ for subsequent regressions as expected. The Rating coefficient is positive and significant in regressions 1 to 5 and 6 at $10 \%$ and $5 \%$ respectively; Table 5 provides evidence that it is due to the HY issues. We also test for the choice of issue Maturity on CAR. The stylized facts clearly show the maturity distribution (Figure 2) of $98 \%$ of $\mathrm{HY}$ issues in $10-15$ years (short maturity) range and $81 \%$ of IG issues in the short maturity and $19 \%$ in the long maturity range. We find the Maturity coefficient to be negative and significant for all regressions; this is due to a small proportion of long maturity IG issues as evidenced in Table 5. In regression 2, we find the $H Y$ coefficient to be positive and significant, as expected from the average CAR observation for HY issues (Table 1).

Table 4. Cross-Sectional Regression Analysis for the Full Sample (1,115 issues) with CAR as the Dependent Variable

\begin{tabular}{|c|c|c|c|c|c|c|}
\hline Variable & Regress 1 & Regress 2 & Regress 3 & Regress 4 & Regress 5 & Regress 6 \\
\hline Constant & $-0.0765^{\star \star}$ & $-0.0965^{\star * *}$ & $-0.0983^{\star * \star}$ & $-0.1093^{\star \star *}$ & $-0.1239^{\star * *}$ & $-0.1392^{\star * *}$ \\
\hline $\begin{array}{l}\text { LOG (Total } \\
\text { Assets) }\end{array}$ & $0.0083^{\star * *}$ & $0.0083^{\star * *}$ & $0.0086^{* * *}$ & $0.0092^{\star \star \star}$ & $0.0118^{\star * *}$ & $0.0123^{\star * *}$ \\
\hline Debt Ratio & 0.0353 & 0.0200 & 0.0153 & 0.0068 & 0.0190 & 0.0292 \\
\hline SIC & 0.0006 & 0.0007 & 0.0006 & 0.0005 & 0.0008 & 0.0005 \\
\hline Tobin's Q & $0.0085^{\star}$ & $0.0085^{\star}$ & $0.0088^{\star}$ & $0.0091^{\star}$ & $0.0099^{* *}$ & $0.0094^{\star}$ \\
\hline Principal/TA & -0.0031 & -0.0027 & -0.0027 & -0.0024 & -0.0017 & -0.0026 \\
\hline Coupon & $0.0027^{\star * *}$ & $0.0025^{\star *}$ & $0.0025^{\star *}$ & $0.0023^{*}$ & $0.0021^{*}$ & $0.0023^{\star}$ \\
\hline Rating & $0.0001^{\star}$ & $0.0018^{\star}$ & $0.0016^{\star}$ & $0.0021^{\star}$ & $0.0018^{\star}$ & $0.0024^{\star *}$ \\
\hline Covenant & -0.0007 & -0.0016 & -0.0017 & -0.0004 & -0.0006 & -0.0003 \\
\hline Call Protection & 0.0001 & -0.0001 & 0.0001 & -0.0001 & -0.0002 & 0.0001 \\
\hline Maturity & $-0.0006^{\star * *}$ & $-0.0005^{\star \star}$ & $-0.0005^{\star \star}$ & $-0.0005^{\star *}$ & $-0.0004^{\star}$ & $-0.0005^{\star \star}$ \\
\hline HY & & $0.0155^{\star \star}$ & $0.0237^{* * *}$ & $0.0280^{\star * *}$ & $0.0218^{\star * *}$ & $0.0400^{* * *}$ \\
\hline Split & & & -0.0001 & $-0.0066^{\star *}$ & $-0.0070^{\star *}$ & -0.0003 \\
\hline $\mathrm{HY}^{\star}$ Split & & & $-0.0137^{\star \star}$ & & & $-0.0129^{* *}$ \\
\hline Refund/MW & & & & 0.0043 & -0.0068 & 0.0040 \\
\hline $\mathrm{HY}^{\star}$ Refund/MW & & & & $-0.0164^{\star * *}$ & & $-0.0161^{\star * *}$ \\
\hline FCF & & & & & $-0.0022^{\star *}$ & $-0.0026^{\star * *}$ \\
\hline $\mathrm{HY}^{\star} \mathrm{FCF}$ & & & & & $-0.0076^{\star *}$ & $-0.0061^{\star *}$ \\
\hline Adjusted R-sq & 0.0137 & 0.0168 & 0.0216 & 0.0216 & 0.0243 & 0.0282 \\
\hline F-stat & 2.5442 & 2.7312 & 2.8878 & 2.7587 & 2.8487 & 2.9008 \\
\hline $\operatorname{Prob}($ F-statistic) & 0.0049 & 0.0017 & 0.0004 & 0.0005 & 0.0002 & 0.0001 \\
\hline
\end{tabular}

${ }^{* * *},{ }^{* *}$, and ${ }^{*}$ indicate significance at the $1 \%, 5 \%$, and $10 \%$ level for one-tailed test. 
We further test for opacity in HY issues by using Split as the proxy. The interaction variable coefficient in regression $3 H Y^{\star}$ Split is negative and significant at 5\% level, confirming high level of opacity and information asymmetry in HY firms. Stylized facts suggest that the HY issues provide strong call protection, we use the Refund/MW variable as the measure that weakens the call protection. In regression 4 , we find the coefficient of the interaction variable $H Y^{\star}$ Refund/MW to be negative and significant at $1 \%$ level. Providing further evidence that the strong call protection is desired in HY issues to mitigate investor's high ratings-upgrade risk. The positive and significant CAR for the HY issues provides strong evidence that the ERC can mitigate additional financial distress resulting from the restrictive call protection. The overall CAR for the IG issues is not significant likely due to the majority of the IG issues falling in the lower half of the IG rating spectrum.

Finally, to test the hypothesis that the ERC increase managerial entrenchment in $\mathrm{HY}$ firms we use the $F C F$ variable as the measure. In regression 5, the coefficient of the interaction variable $H Y^{\star} F C F$ is negative and significant at $5 \%$ level providing evidence that the ERC in HY issues increases managerial entrenchment (Billet et al. 2007). Regression 6 provides results with all the control variables and interaction variables.

Table 5. Cross-sectional regression analysis for high yield and investment grade issues with CAR as the dependent variable

\begin{tabular}{|c|c|c|}
\hline Variable & $\begin{array}{l}\text { High Yield } \\
\text { (HY) }\end{array}$ & $\begin{array}{l}\text { Investment Grade } \\
\text { (IG) }\end{array}$ \\
\hline Constant & $-0.1376^{\star *}$ & $-0.0846^{\star * *}$ \\
\hline LOG (Total Assets) & $0.0169^{* * *}$ & $0.0057^{\star *}$ \\
\hline Debt Ratio & 0.027 & -0.042 \\
\hline SIC & -0.0001 & 0.0009 \\
\hline Tobin's Q & $0.0206^{\star}$ & 0.0037 \\
\hline Principal/TA & -0.0050 & 0.0025 \\
\hline Coupon & 0.0031 & $0.0020^{\star}$ \\
\hline Rating & $0.0041^{\star *}$ & 0.0006 \\
\hline Covenant & -0.0015 & 0.0057 \\
\hline Call Protection & -0.0007 & 0.0001 \\
\hline Maturity & -0.0003 & $-0.0005^{\star \star}$ \\
\hline Split & $-0.0132^{\star *}$ & -0.0005 \\
\hline Refund/MW & $-0.0178^{\star * *}$ & 0.0022 \\
\hline FCF & $-0.0126^{* * *}$ & -0.0008 \\
\hline Number of Obs. & 548 & 567 \\
\hline Adjusted R-sq & 0.0380 & 0.0116 \\
\hline F-stat & 2.6611 & 1.6146 \\
\hline Prob(F-statistic) & 0.0013 & 0.0769 \\
\hline
\end{tabular}

${ }^{* * *},{ }^{* *}$, and ${ }^{*}$ indicate significance at the $1 \%, 5 \%$, and $10 \%$ level for one-tailed test.

\section{Conclusions}

The firm's choice of security design parameters is largely influenced by the market frictions. The HY and IG issues contain parameters designed to counter disparate agency issues. We investigate the role of call provision and ERC in 1,115 HY and IG ERC protected issues during 1986-2012 by assessing stock price reaction around the issue date. We find positive and significant stock price reaction at the issuance of HY issues and not the IG issues. We find that $87 \%$ of the issues include call provision. Since the HY issues present high rating-upgrade risk (high likelihood of a call due to ratings improvement) to the investors, they are issued in both high and low interest rate periods. Majority of the IG issues are rated in the lower half of the IG rating spectrum signalling prospects of fewer growth options and are issued from 2007 onwards, presenting low growth-options risk (call due to realization of growth options for high quality firms) and virtually eliminating reinvestment risk (call due to declining interest rates). Almost all HY issues have short maturity to enable refinancing in case of credit rating improvement (Diamond 1991) and majority of IG issues have short maturity to fully exploit growth options.

The stylized facts show that the HY issues provide strong call protection and a call premium to mitigate high ratingsupgrade risk. Stock price reaction provides evidence of presence of opacity and the desire for strong call protection in $\mathrm{HY}$ issues. Conversely, the strong call protection can reduce financial flexibility, highly desired in HY firms, resulting in increased financial distress (Nash 2003, McDaniel 1986, Anderson 1999, Thatcher 1985). ERC is appropriately included to mitigate this risk. The IG issues provide weak call protection and are callable at par affording financial flexibility to fully exploit fewer growth options. The overall insignificant stock price reactions suggest that either ERC is deemed ineffective in mitigating financial distress due to non-realization of growth options or the risk is so low that the inclusion of ERC is redundant.

Finally, we find evidence of increased managerial entrenchment in HY issuing firms due to ERC. The overall positive stock price reaction to the $\mathrm{HY}$ issues provides evidence that the reduction in agency cost of debt supersedes the increase in managerial entrenchment affirming Bae et al. (1994).

\section{References}

Anderson C (1999) Financial contracting under extreme uncertainty: an analysis of Brazilian corporate debentures. Journal of Financial Economics 51: 45-84. https://doi.org/10.1016/ S0304-405X(98)00043-9

Asquith P, Wizman T (1990) Event risk, covenants, and bondholder returns in leveraged buyouts. Journal of Financial Economics 27: 195-213. https://doi.org/10.1016/0304405X(90)90026-V 
Avramov D, Chordia T, Jostova G, Philipov A (2007) Momentum and credit rating. Journal of Finance 62: 2503-2520. https:// doi.org/10.1111/j.1540-6261.2007.01282.x

Bae S, Klein D, Padmaraj R (1994) Event risk bond covenants, agency costs of debt and equity, and stockholder wealth. Financial Management 23: 28-41. https://doi. org/10.2307/3666081

Barnea A, Haugen R, Senbet L (1980) A rationale for debt maturity structure and call provisions in the agency theoretic framework. Journal of Finance 35: 1223-1234. https://doi. org/10.1111/j.1540-6261.1980.tb02205.x

Begley J (1994) Restrictive covenants included in public debt agreements: an empirical investigation. Unpublished working paper. University of British Columbia, Vancouver.

Bhanot K, Mansi S, Wald J (2010) Takeover risk and the correlation between stocks and bonds. Journal of Empirical Finance 17: 381-393. https://doi.org/10.1016/j.jempfin.2009.10.006

Billet M, Dolly King T, Mauer D (2007) Growth opportunities and the choice of leverage, debt maturity, and covenants. Journal of Finance 62: 697-730. https://doi.org/10.1111/j.15406261.2007.01221.x

Billet M, Hribar P, Liu Y (2015) Shareholder-Manager alignment and the cost of debt. Working Paper. https://doi.org/10.2139/ ssrn. 958991

Bodie Z, Taggart R (1978) Future investment opportunities and the value of the call provision on a bond. Journal of Finance 33: 1187-1220. https://doi.org/10.1111/j.1540-6261.1978. tb02056.x

Cook D, Easterwood J (1994) Poison put bonds: an analysis of their economic role. Journal of Finance 49: 1905-1920. https:// doi.org/10.1111/j.1540-6261.1994.tb04787.x

Cook D, Easterwood J, Martin J (1992) Bondholder wealth effects of management buyouts. Financial Management 21: 102-113. https://doi.org/10.2307/3665684

Crabbe L (1991) Event risk: an analysis of losses to bondholders and "super poison put" bond covenants. Journal of Finance 46: 689-706. https://doi.org/10.1111/j.1540-6261.1991.tb02680.x

Cremers M, Nair V, Wie C (2007) Governance mechanisms and bond prices. Review of Financial Studies 20: 1359-1388. https://doi.org/10.1093/revfin/hhm006

Diamond D (1991) Debt maturity structure and liquidity risk. Quarterly Journal of Economics 106: 709-737. https://doi. org/10.2307/2937924

Ederington L, Stock D (2002) Impact of call features on corporate bond yields. Journal of Fixed Income 12: 58-68. https://doi. org/10.3905/jfi.2002.319325

Fields J, Kidwell A, Klein L (1994) Coupon resets versus poison puts: the valuation of event risk provisions in corporate debt. Financial Services Review 3: 143-156. https://doi. org/10.1016/1057-0810(94)90019-1

Ghouma H (2017) How does managerial opportunism affect the cost of debt financing? Research in International Business and Finance 39: 13-29. https://doi.org/10.1016/j.ribaf.2016.07.007

Gilson S, Warner J (1998) Private versus public debt: evidence from firms that replace bank loans with junk bonds. Working paper, Harvard Business School.
Guedes J, Opler T (1996) The determinants of the maturity of corporate debt issues. Journal of Finance 51: 1809-1833. https://doi.org/10.1111/j.1540-6261.1996.tb05227.x

Harris M, Raviv A (1990) Capital structure and the information role of debt. Journal of Finance 45: 321-349. https://doi. org/10.1111/j.1540-6261.1990.tb03693.x

Harvey C, Lins K, Roper A (2004) The effect of capital structure when expected agency costs are extreme. Journal of Financial Economics 74: 3-30. https://doi.org/10.1016/j. jfineco.2003.07.003

Hege U, Hennessey C (2010) Acquisition values and optimal financial (in)flexibility. Review of Financial Studies 23: 28662899. https://doi.org/10.1093/rfs/hhq017

Helwege J, Huang J, Wang Y (2016) Debt covenants and crosssectional equity returns. Management Science 63: 1657-2048. https://doi.org/10.1287/mnsc.2015.2381

Jensen M (1986) Agency costs of free cash flow, corporate finance and takeovers. American Economic Review 76: 323-339 https://www.jstor.org/stable/1818789

Jensen M, Meckling W (1976) Theory of the firm: managerial behavior, agency costs, and ownership structure. Journal of Financial Economics 3: 305-360. https://doi.org/10.1016/0304405X(76)90026-X

Kahan M, Klausner M (1993) Antitakeover provisions in bonds: bondholder protection or management entrenchment? UCLA Law Review (April): 931-982.

Kahan M, Yermack D (1998) Investment opportunities and the design of debt securities. Journal of Law, Economics and Organization 14: 136-151. https://doi.org/10.1093/oxfordjournals.jleo.a023394

Kish R, Livingston M (1992) Determinants of the call option on corporate bonds. Journal of Banking \& Finance 16: 687-703. https://doi.org/10.1016/0378-4266(92)90002-H

Korkeamaki T, Moore W (2004) Convertible bond design and capital investment: the role of call provisions. Journal of Finance 59: 391-405. https://doi.org/10.1111/j.15406261.2004.00636.x

Lehn K, Poulsen J (1989) Free cash flow and stockholder gains in going private transactions. Journal of Finance 77: 1-788. https://doi.org/10.1111/j.1540-6261.1989.tb04390.x

Leland H (1994) Corporate debt value, bond covenants, and optimal capital structure. Journal of Finance 49: 1213-1252. https://doi.org/10.1111/j.1540-6261.1994.tb02452.x

McDaniel M (1986) Bondholders and corporate governance. The Business Lawyer 41: 413-460. https://doi.org/10.1016/0304405X(86)90049-8

Mikkelson W, Partch M (1986) Valuation effects of security offerings and the issuance process. Journal of Financial Economics 15: 31-60. https://doi.org/10.1016/0304-405X(86)90049-8

Miller D (1999) The market reaction to international cross-listing: evidence from depositary receipts. Journal of Financial Economics 51: 103-123. https://doi.org/10.1016/S0304405X(98)00045-2

Nanda V, Yun Y (1996) Financial innovation and investor wealth: a study of the poison put in convertible bonds. Journal of Corporate Finance 3: 1-22. https://doi.org/10.1016/S09291199(96)00005-3 
Nash R, Netter J, Poulsen A (2003) Determinants of contractual relations between, shareholders and bondholders: investment opportunities and restrictive covenants. Journal of Corporate Finance 9: 201-232. https://doi.org/10.1016/S09291199(02)00007-X

Perumpral S, Davidson D, Sen N (1999) Event risk covenants and shareholder wealth: ethical implications of the "poison put" provision in bonds. Journal of Business Ethics 22: 119-132. https://doi.org/10.1023/A:1006091829986

Robbins E, Schatzberg J (1986) Callable bonds: a risk-reducing signalling mechanism. Journal of Finance 41: 935-949. https:// doi.org/10.1111/j.1540-6261.1986.tb04558.x

Roth G, McDonald C (1999) Shareholder-management conflict and event risk covenants. Journal of Financial Research 22: 207-225. https://doi.org/10.1111/j.1475-6803.1999.tb00723.x

Scholes M, Williams J (1977) Estimating betas from nonsynchronous data. Journal of Financial Economics 5: 309-327. https:// doi.org/10.1016/0304-405X(77)90041-1

Shleifer A, Vishny R (1989) Management entrenchment: the case of manager-specific investments. Journal of Financial Economics 25: 123-140. https://doi.org/10.1016/0304405X(89)90099-8

Smith C, Smithson C, Wilford D (1989) Managing financial risk. Journal of Applied Corporate Finance 2: 27-48. https://doi. org/10.1111/j.1745-6622.1989.tb00172.x
Stulz R (1990) Managerial discretion and optimal financing policies. Journal of Financial Economics 26: 3-27. https://doi. org/10.1016/0304-405X(90)90011-N

Tewari M, Ramanlal P, Byrd A (2015) Callable bonds, reinvestment risk, and credit rating improvements: role of the call premium. Journal of Financial Economics 115: 349-360. https://doi.org/10.1016/j.jfineco.2014.09.011

Thatcher J (1985) The choice of call provision terms: evidence of the existence of agency costs of debt. Journal of Finance 40: 549-561. https://doi.org/10.1111/j.1540-6261.1985.tb04972.x

Warga A, Welch I (1993) Bondholder losses in leveraged buyouts. Review of Financial Studies 6: 959-982. https://doi. org/10.1093/rfs/6.4.959

Winn W, Hess A (1959) The value of the call privilege. Journal of Finance 14: 182-195. https://doi.org/10.1111/j.1540-6261.1959. tb01580.x

Xu Q (2017) Kicking maturity down the road: early refinancing and maturity management in the corporate bond market. Review of Financial Studies 31: 3061-3097. https://doi. org/10.1093/rfs/hhx116

Zhang X, Zhou S (2018) Bond covenants and institutional blockholdings. Journal of Banking and Finance 96: 136-152. https:// doi.org/10.1016/j.jbankfin.2018.09.006

\section{Notations}

\section{Abbreviations}

ERC - Event Risk Covenant,

HY - High yield,

IG - Investment Grade,

CAR - Cumulative Abnormal Return,

LBO - Leveraged,

CRSP - Center for Research in Security Prices.

\section{APPENDIX}

